\title{
Reproductive performance of Jersey and Fleckvieh $\times$ Jersey heifers and cows maintained on a pasture-based feeding system
}

\author{
S. Goni ${ }^{1,4 \#}$, C.J.C. Muller ${ }^{2}$, B. Dube ${ }^{3,4}$ \& K. Dzama ${ }^{4}$ \\ ${ }^{1}$ Döhne Agricultural Development Institute, Private Bag X15, Stutterheim 4930, South Africa \\ ${ }^{2}$ Western Cape Department of Agriculture, Research and Technology Development Services, Directorate: Animal \\ Sciences, Private Bag X1, Elsenburg 7607, South Africa; \\ ${ }^{3}$ Agricultural Research Council, Private Bag X2, Irene 0062, South Africa \\ ${ }^{4}$ Department of Animal Sciences, University of Stellenbosch, Stellenbosch 7600, South Africa
}

(Received 20 June 2014; Accepted 27 July 2015; First published online 30 September 2015)

Copyright resides with the authors in terms of the Creative Commons Attribution 2.5 South African Licence.

See: http://creativecommons.org/licenses/by/2.5/za

Condition of use: The user may copy, distribute, transmit and adapt the work, but must recognise the authors and the South African Journal of Animal Science.

\begin{abstract}
Crossbreeding is regarded as a faster way than using pure dairy breeds to improve the reproductive performance of dairy cows, which is pivotal to farm income. The reproductive performances of Jersey and Fleckvieh $\times$ Jersey $(F \times J)$ heifers and cows were compared in a pasture-based production system. Heifers were inseminated when showing signs of heat from 13 months old and cows from 40 days post calving. Using insemination records and pregnancy check results, fertility traits were derived and compared between breeds, using analysis of variance for continuous records. Age at first insemination and conception age for heifers did not differ between the two breeds, resulting in a similar age at first calving. For cows, the mean $( \pm \mathrm{SE})$ interval from calving to first insemination was shorter for $\mathrm{F} \times \mathrm{J}$ cows, being $76.7 \pm 2.2$ days compared with $82.4 \pm 2.5$ days for Jersey cows. A larger proportion of $\mathrm{F} \times \mathrm{J}$ cows were inseminated within 80 days post calving, compared with the Jersey cows ( 0.70 and 0.54 , respectively). Furthermore, the proportion of cows confirmed pregnant by 100 days in milk was higher for $\mathrm{F} \times \mathrm{J}$ cows in comparison with Jersey cows, being 0.79 and 0.66 , respectively. Although the absolute number of days between calving and conception (days open) was slightly less for $\mathrm{F} \times \mathrm{J}$ cows in comparison with Jersey cows (104.8 \pm 6.8 and $114.8 \pm 8.1$ days, respectively), the difference was not significant. These results indicate the potential of improving reproductive performance of Jersey cows through crossbreeding with the dual-purpose Fleckvieh.
\end{abstract}

Keywords: Artificial insemination, crossbreeding, female and fertility, intensive production system

\#Corresponding author: sindisile.goni@drdar.gov.za

\section{Introduction}

The financial viability of a dairy enterprise depends on the consistency and efficiency of milk production and reproductive performance of dairy cows. Thus, modern economically derived breeding objectives usually include fitness-related or functional traits, such as fertility and survival (Fuerst-Waltl \& Fuerst, 2010). The productive life of a dairy cow is influenced by her reproductive performance, depicted by age at first calving, calving intervals, length of each lactation and survival to the next lactation. While economic values of production traits may fluctuate with milk prices and production costs, efficient reproduction and high survival are likely to be valuable under all future market scenarios (Goddard, 2009). It is becoming increasingly evident that fertility is declining with rising milk yields for some dairy breeds in South Africa (Makgahlela et al., 2008). Mostert et al. (2010) estimated genetic parameters for South African dairy breeds and showed that calving interval $(\mathrm{Cl})$ had increased genetically from 1980 for Jerseys and Holsteins, being 0.59 and 1.25 days per year, respectively. Genetic selection for high milk production has thus resulted in concerns about female fertility, calving ease and survival in the purebred dairy breeds, probably owing to the limited genetic ability of animals for coping (Oltenacu \& Broom, 2010). However, there is no consensus regarding the mechanism of the effect of yield on female fertility (Pryce et al., 2004).

The reduction in female fertility may be attributed partly to rising levels of inbreeding, which characterize. most modern dairy breeds (McAllister, 2002). An accumulation of inbreeding has been reported at a slightly higher rate in the South African (SA) Jersey population compared with other dairy purebreds, (Maiwashe et al., 2006). Du Toit et al. (2012) also reported significant negative effects of inbreeding on functional herd life in the first and second lactations of SA Jersey cows. Smith et al. (1998) observed that 
inbreeding decreased the mature equivalent production of milk, fat and protein during first lactation by 27 , 0.9 and $0.8 \mathrm{~kg}$, respectively, while the lifetime production of milk, fat and protein were reduced by $177,6.0$ and $5.5 \mathrm{~kg}$, respectively, per 1\% increase in inbreeding. A decreased survival rate of Jerseys has been observed as the level of inbreeding increased. Survival is likely to have a greater negative impact on the financial health of the dairy enterprise than production losses (Thompson et al., 2000).

Crossbreeding is one way of mitigating inbreeding by improving health, fertility and survival. This is attributable to differences between breeds that are much greater than differences within breed, and extra benefits may be achieved from heterosis (Caraviello, 2004). Crossbreeding, which has not been considered in some dairy circles, is becoming a more popular concept in an industry now dominated by purebred herds. Most research on dairy crossbreeding in the USA used Holsteins as the base population. Little information is available on the effect of crossbreeding in South African dairy cows. Heins et al. (2008) compared the production and reproduction performance of Jersey $\times$ Holstein and Holstein cows and showed that crossbred animals had a 23-day advantage for days open (DO) compared with pure dairy breeds. Earlier results (Muller, 2011) indicated that in comparison with Holsteins, Fleckvieh $\times$ Holstein cows required fewer inseminations per conception (1.93 vs. 2.79) and had shorter intervals from calving to first insemination (89 vs. 97 days) and from calving to conception (132 vs. 172 days). Calving ease, fertility, longevity and calf vitality are some of the important advantages crossbreds offer over purebreds (Caraviello, 2004).

With the exception of countries that use purely pasture-based dairying systems, Jerseys have received little attention in dairy crossbreeding, being a breed with relatively small numbers. Grazing is often considered the most sustainable way of producing milk, owing to lower production costs, higher quality products and greater social acceptance (Broom et al., 2013). In many parts of the world, pasture-based systems are synonymous with compact seasonal calving to match feed demand and pasture growth. The genotype-by-environment interaction determines the success of a production system; thus, the choice of breed plays an important role. Little attention has been given to the use of dual-purpose breeds in dairy crossbreeding programmes. The Fleckvieh is a dual-purpose breed that is characterized by excellent reproductive performance (Piccand et al., 2013). Dual-purpose breeds provide an opportunity to maintain higher milk yield of cows while improving fertility, longevity and beef production. Against this background, the objective of this study was to compare the reproductive performance of Jersey and Fleckvieh $\times$ Jersey cows and heifers maintained in a pasture-based feeding system.

\section{Materials and Methods}

The study was conducted at Elsenburg Research Farm, Western Cape Department of Agriculture. Elsenburg is situated approximately $50 \mathrm{~km}$ east of Cape Town at an altitude of $177 \mathrm{~m}$, longitude $18^{\circ} 50^{\prime}$ and latitude $33^{\circ} 51^{\prime}$ in the winter rainfall region of South Africa. The area has a typical Mediterranean climate with short, cool, wet winters and long, hot, dry summers, with an average annual rainfall of $650 \mathrm{~mm}$.

Reproductive performance data were collected over six years between 2008 and 2013. A total of 155 records for 64 Jersey cows and 190 records for 69 Fleckvieh $\times$ Jersey $(F \times J)$ cows were used as experimental animals to compare cow reproduction. Fifty-nine Jersey and $80 \mathrm{~F} \times \mathrm{J}$ heifers were included in the analysis of reproductive performance. All crossbred cows and heifers that ranged from $25 \%$ to $75 \%$ Fleckvieh were included in the study. They were all regarded collectively as $\mathrm{F} \times \mathrm{J}$, regardless of the sire that was used to reach these percentages. When observed on standing heat, heifers were inseminated from 13 months old and cows from 40 days post calving. Hormonal treatment to get cows pregnant was applied when cows that were 150 days in milk were not confirmed pregnant.

When heifers were confirmed pregnant, they were put on kikuyu pastures until calving. From four weeks before calving, heifers were supplemented with a commercial dry cow meal containing $150 \mathrm{~g} / \mathrm{kg}$ of crude protein (CP) at $3 \mathrm{~kg}$ per animal per day. After calving, the Jersey and $\mathrm{F} \times \mathrm{J}$ cows were put on irrigated cultivated kikuyu pastures. All lactating cows received a daily commercial concentrate meal in a post-parlour feeding facility at $7 \mathrm{~kg}$ per animal, regardless of level of daily milk yield and lactation stage. In winter, kikuyu pasture was supplemented with a pasture replacement mixture consisting of oat and lucerne hay, and soybean oil cake meal.

For heifers, the traits recorded and analysed included age at first service (AFS), heifer conception rate (HCR), age of heifers at conception (ConAge) and number of services per conception (SPC). The reproduction traits recorded and analysed for cows were interval from calving to first service (CFS), conception rate (CR), whether first service occurred before 80 days in milk ( $F S<80 \mathrm{~d}$ ), number of services per conception (SPC), and interval from calving to conception or days open (DO). The summary statistics for these traits are presented in Tables 1 and 2. 
Table 1 Summary statistics for reproductive traits analysed for Jersey and Fleckvieh $\times$ Jersey $(F \times J)$ heifers

\begin{tabular}{lcccccc}
\hline Parameters & Breed & Number & Mean & SD & Min & Max \\
\hline \multirow{2}{*}{ AFS (months) } & Jersey & 59 & 15.3 & 1.8 & 12.3 & 27.4 \\
\multirow{2}{*}{ HCR } & F $\times \mathrm{J}$ & 80 & 15.3 & 2.2 & 12.0 & 23.6 \\
& Jersey & 59 & 0.89 & 0.30 & 0.00 & 1.00 \\
EAFC & $\mathrm{F} \times \mathrm{J}$ & 80 & 0.92 & 0.26 & 0.00 & 1.00 \\
& Jersey & 53 & 25.81 & 2.93 & 21.53 & 36.59 \\
SPC & $\mathrm{F} \times \mathrm{J}$ & 74 & 26.34 & 2.68 & 21.83 & 32.81 \\
& Jersey & 53 & 1.66 & 0.93 & 1 & 5 \\
& $\mathrm{~F} \times \mathrm{J}$ & 74 & 2.04 & 1.17 & 1 & 6 \\
\hline
\end{tabular}

AFS: age at first service; HCR: heifer conception rate; EAFC: expected age at first calving;

SPC: number of services per conception; SD: standard deviation.

Table 2 Summary statistics for reproductive traits for Jersey and Fleckvieh $\times$ Jersey $(F \times J)$ cows

\begin{tabular}{lcccccc}
\hline Parameters & Breed & Number & Mean & SD & Min & Max \\
\hline \multirow{2}{*}{ CFS (days) } & Jersey & 155 & 81 & 28 & 17 & 246 \\
& F $\times J$ & 190 & 75 & 17 & 25 & 189 \\
CR & Jersey & 155 & 0.74 & 0.43 & 0 & 1.00 \\
& F $\times J$ & 190 & 0.85 & 0.35 & 0 & 1.00 \\
FS $<80 d$ & Jersey & 155 & 0.54 & 0.49 & 0 & 1.00 \\
SPC & F $\times J$ & 190 & 0.70 & 0.45 & 0 & 1.00 \\
& Jersey & 117 & 1.93 & 1.29 & 1 & 7 \\
DO (days) & F $\times J$ & 162 & 1.74 & 1.00 & 1 & 5 \\
& Jersey & 117 & 121 & 66 & 17 & 429 \\
& F $\times J$ & 162 & 108 & 50 & 34 & 288 \\
\hline
\end{tabular}

CFS: interval calving to first service; CR: conception rate; FS<80d: first service within 80 days after calving;

SPC: services per conception; DO: days open; SD: standard deviation.

The two data sets were analysed using the general linear models (GLM) procedures of SAS (2009) to estimate the effects of breed, calving age, year of service and parity on fertility traits. Least square means were calculated for each effect, where they were separated using the PDIFF STDERR procedures of SAS (2009). The following model was adopted for the traits in each of the two breeds for reproductive performance:

$$
\mathbf{Y}_{\mathrm{ijkl}}=\boldsymbol{\mu}+\mathbf{B}_{\mathrm{i}}+\mathbf{Y}_{\mathrm{j}}+\mathbf{S}_{\mathrm{k}}+\boldsymbol{\beta}_{0}(\mathrm{CAGE})_{\mathrm{ijkl}}+\mathbf{e}_{\mathrm{ijkl}}
$$

where: $Y_{i j k l}$ is an observation for each trait, $\mu$ is the population mean, $B_{i}$ is the effect of the $i^{\text {th }}$ breed, $Y_{j}$ is the effect of the $j^{\text {th }}$ year of calving, $S_{k}$ is the effect of the $k^{\text {th }}$ season of calving, $\beta_{0}$ is the linear regression coefficient of the observed trait on calving age; (CAGE) $)_{\mathrm{ijkl}}$ is the calving age, and $\mathrm{e}_{\mathrm{ijkl}}$ is the random error. Calving age was included as a linear covariate in the model for CFS, FS $<80 \mathrm{~d}$ and DO. To accommodate the repeated records in the analyses of records for adult cows, year of calving was included as a random effect. Season of calving was defined as summer (October - March) and winter (April - September). 


\section{Results and Discussion}

The results presented in Table 4 show that while breed affected $(P<0.05)$ most of the reproductive traits of Jersey and $\mathrm{F} \times \mathrm{J}$ cows, no differences were observed in the reproductive performance of Jersey and $\mathrm{F} \times \mathrm{J}$ heifers (Table 3). Because this was their first service and they were under similar management practices, this could have caused these heifers to have equal chances of performing at a certain level of reproductive performance. Inseminator proficiency is an important aspect of reproduction management in dairy herds, and could have masked the effect of breed. Most of the work reviewed reported largely on Holsteins and their crossbreds, since Holsteins have received more attention than Jersey in dairy crossbreeding.

The pregnancy rate of Jersey and $\mathrm{F} \times \mathrm{J}$ cows reared on a pasture-based system differed $(P<0.001)$, with crossbreds achieving a $13 \%$ higher pregnancy rate compared with Jersey cows. Without direct comparison, Anderson et al. (2007) reported a pregnancy rate of 6 percentage units greater for Jersey $x$ Holsteins than for pure Holsteins. Crossbred cows and heifers were observed to be pregnant sooner after each calving, had higher non-return rates, fewer services and shorter gestation lengths than purebred Holsteins (Schaeffer et al., 2011). The CFS was significantly longer in pure Jersey cows (82.4 \pm 2.5 days) compared with the crossbred cows $(76.7 \pm 2.2$ days). This may lead to longer calving intervals for Jersey cows, translating to fewer calves during the reproductive lifetime of these cows. The percentage of cows inseminated for the first time within the first 80 days of calving was $16 \%$ higher $(P<0.01)$ for crosses in comparison to pure Jersey cows. This could be attributed to the $\mathrm{F} \times \mathrm{J}$ cows having experienced an easier calving-down process, resulting in quicker recovery of the reproductive system. Auldist et al. (2007) reported higher first-service conception rates with higher proportions of confirmed pregnancies for Jersey $\times$ Holstein compared with Holstein herds.

Table 3 Least square means $( \pm$ SE) depicting breed effect on reproductive performance of Jersey and Fleckvieh $\times$ Jersey $(F \times J)$ heifers

\begin{tabular}{lcc}
\hline Parameters & Jersey & $F \times J$ \\
\hline Number of records & 59 & 80 \\
HCR & $0.87^{\mathrm{a}} \pm 0.04$ & $0.94^{\mathrm{a}} \pm 0.03$ \\
AFS $(\mathrm{m})$ & $15.4^{\mathrm{a}} \pm 0.2$ & $15.1^{\mathrm{a}} \pm 0.2$ \\
AFC (m) & $16.5^{\mathrm{a}} \pm 0.4$ & $16.7^{\mathrm{a}} \pm 0.4$ \\
EAFC (m) & $26.0^{\mathrm{a}} \pm 0.4$ & $26.2^{\mathrm{a}} \pm 0.3$ \\
SPC & $1.7^{\mathrm{a}} \pm 0.2$ & $1.9^{\mathrm{a}} \pm 0.1$
\end{tabular}

${ }^{a, b}$ Means within the same row with different superscripts are significantly different $(P<0.05)$

HCR: heifer conception rate; AFS: age at first service; AFC: age at first conception;

EAFC: expected age at first calving; SPC: services per conception; SE: standard error.

Table 4 Least square means ( \pm SE) depicting breed effect on reproductive performance of Jersey and Fleckvieh $\times$ Jersey $(F \times J)$ cows

\begin{tabular}{lcc}
\hline Parameters & Jersey & $\mathrm{F} \times \mathrm{J}$ \\
\hline Number of records & 155 & 190 \\
CR & $0.66^{\mathrm{a}} \pm 0.03$ & $0.79^{\mathrm{b}} \pm 0.03$ \\
CFS (d) & $82.4^{\mathrm{b}} \pm 2.5$ & $76.7^{\mathrm{a}} \pm 2.2$ \\
FS $<80$ (d) & $0.54^{\mathrm{a}} \pm 0.05$ & $0.70^{\mathrm{b}} \pm 0.05$ \\
DO (d) & $114.8^{\mathrm{a}} \pm 8.1$ & $104.8^{\mathrm{a}} \pm 6.8$ \\
SPC & $1.7^{\mathrm{a}} \pm 0.1$ & $1.6^{\mathrm{a}} \pm 0.1$
\end{tabular}

\footnotetext{
${ }^{\mathrm{a}, \mathrm{b}}$ Means within the same row with different superscripts are significantly different $(P<0.05)$.
}

CR: conception rate; CFS: calving to first service; FS <80d: first service within 80 days after calving;

SPC: services per conception; DO: days open; SE: standard error. 
Using a small dataset, Muller (2011) found that $\mathrm{F} \times \mathrm{J}$ and Jersey cows required 2.5 and 2.9 inseminations, respectively, per conception. The interval from calving to first insemination was 72 versus 91 days, and the interval from calving to conception was 131 days versus 168 for $F \times J$ and Jersey cows, respectively. Heins et al. (2006) also found that Normande/Holsteins and Montbéliarde/Holsteins crossbreds had significantly higher first-service conception rates compared with pure Holsteins. While the number of days between calving and conception (DO) were 10.3 days fewer for crosses in comparison with Jersey cows, the difference between the breeds was not significant. Heins et al. (2008) found Jersey-Holstein $(\mathrm{J} \times \mathrm{H})$ cows had significantly fewer days open (DO) than pure Holsteins, and a significantly greater proportion of $\mathrm{J} \times \mathrm{H}$ were pregnant at 150 and 180 days postpartum compared with pure Holsteins. Dechow et al. (2007) also reported that DO was significantly fewer for crosses of Brown Swiss/Holsteins than pure Holsteins. This difference is probably related to a large variation in uterine involution in the breeds. The lower reproductive performance observed with cows selected solely for high milk yield was associated with lower energy balance in early lactation, greater partitioning of additional nutrients towards milk production, inability to achieve desired grass intake from pasture and reduced plasma glucose and insulin-like growth factor-1 concentrates (Dillon et al., 2006). This variation in reproductive efficiency suggests that hybrid vigour is a major factor in the superior reproductive efficiency of the crosses (Prendiville et al., 2011).

Table 5 shows the least square means for the effect of birth year, calving year and service year on pooled reproductive performance of Jersey and $\mathrm{F} \times \mathrm{J}$ cows and heifers. Birth year only had a significant effect on age at first insemination of heifers in both breeds. Age at first service was older $(P<0.05)$ in 2011 , which was 2 to 3 months older than in the other years. The heifers reached oestrus earlier, and were therefore inseminated earlier at $14.8 \pm 0.4$ and $15.2 \pm 0.3$ months old in 2009 and 2010, respectively. This could have been because of management errors, late detection of oestrus signs, consecutive date of inseminations of cows and low pasture availability leading to later maturing in 2011.

Table 5 Least square means ( \pm SE) depicting year effect on pooled reproductive performance of Jersey and Fleckvieh $\times$ Jersey $(F \times J)$ cows and heifers

\begin{tabular}{|c|c|c|c|c|c|c|}
\hline \multirow[t]{2}{*}{ Variables } & \multirow[t]{2}{*}{ Class } & \multicolumn{5}{|c|}{ Year } \\
\hline & & 2008 & 2009 & 2010 & 2011 & 2012 \\
\hline $\mathrm{CR}$ & ${ }^{1}$ Cows & $0.70^{a} \pm 0.08$ & $0.91^{a} \pm 0.05$ & $0.85^{a} \pm 0.04$ & $0.87^{\mathrm{a}} \pm .04$ & $0.79^{a} \pm 0.04$ \\
\hline $\mathrm{HCR}$ & ${ }^{2}$ Heifers & $1.02^{\mathrm{a}} \pm 0.06$ & $1.01^{a} \pm 0.06$ & $0.97^{\mathrm{a}} \pm 0.05$ & $0.88^{\mathrm{a}} \pm 0.06$ & $0.84^{a} \pm 0.06$ \\
\hline \multirow[t]{2}{*}{ SPC } & ${ }^{1}$ Cows & $1.67^{\mathrm{a}} \pm 0.29$ & $2.01^{a} \pm 0.18$ & $1.60^{a} \pm 0.18$ & $1.67^{\mathrm{a}} \pm 0.16$ & $1.61^{a} \pm 0.17$ \\
\hline & ${ }^{2}$ Heifers & $1.46^{\mathrm{a}} \pm 0.22$ & $1.65^{a} \pm 0.25$ & $2.10^{a} \pm 0.18$ & $1.80^{\mathrm{a}} \pm 0.25$ & $2.45^{a} \pm 0.24$ \\
\hline CFS (d) & ${ }^{1}$ Cows & $84.94^{a} \pm 5.1$ & $74.21^{\mathrm{a}} \pm 3.4$ & $84.81^{a} \pm 3.1$ & $76.08^{a} \pm 2.9$ & $75.50^{\mathrm{a}} \pm 2.9$ \\
\hline $\mathrm{FS}<80(\mathrm{~d})$ & ${ }^{1}$ Cows & $0.57^{\mathrm{a}} \pm 0.10$ & $0.73^{a} \pm 0.07$ & $0.49^{a} \pm 0.07$ & $0.68^{\mathrm{a}} \pm 0.06$ & $0.64^{a} \pm 0.06$ \\
\hline $\mathrm{DO}(\mathrm{d})$ & ${ }^{1}$ Cows & $116.7^{\mathrm{a}} \pm 15.3$ & $121.5^{a} \pm 8.7$ & $122.3^{a} \pm 7.5$ & $114.2^{\mathrm{a}} \pm 7.2$ & $106.6^{\mathrm{a}} \pm 7.2$ \\
\hline $\operatorname{AFS}(\mathrm{m})$ & ${ }^{3}$ Heifers & $15.4^{a} \pm 0.38$ & $14.8^{\mathrm{ab}} \pm 0.40$ & $15.2^{\mathrm{ab}} \pm 0.36$ & $17.1^{\mathrm{ac}} \pm 0.42$ & $15.1^{a} \pm 0.70$ \\
\hline $\mathrm{AFC}(\mathrm{m})$ & ${ }^{3}$ Heifers & $17.1^{\mathrm{a}} \pm 0.53$ & $16.5^{a} \pm 0.60$ & $17.3^{a} \pm 0.56$ & $18.2^{\mathrm{a}} \pm 0.62$ & $15.2^{a} \pm 1.23$ \\
\hline $\operatorname{EAFC}(\mathrm{m})$ & ${ }^{2}$ Heifers & $24.6^{a} \pm 0.57$ & $25.4^{\mathrm{a}} \pm 0.63$ & $26.6^{a} \pm 0.46$ & $25.7^{\mathrm{a}} \pm 0.66$ & $27.2^{a} \pm 0.63$ \\
\hline
\end{tabular}

${ }^{\mathrm{a}, \mathrm{b}}$ Means within the same row with different superscripts are significantly different $(P<0.01)$.

CR: conception rate; HCR: heifer conception rate; SPC: services per conception; CFS: calving to first service;

FS < 80d: first service within 80 days after calving; DO: days open; AFS: age at first service;

AFC: age at first conception; EAFC: expected age at first calving); SE: standard error.

${ }^{1}$ effect of calving year; ${ }^{2}$ effect of year of service; ${ }^{3}$ effect of birth year.

The effect of birth season, service season and calving season on both cows and heifers was not significant $(P>0.05)$ on any of the productive traits. Despite the negative effects of thermal stress during summer, fertility in this study was not impaired in any of the breed groups. Pregnancy rates were more consistent over the seasons when timed artificial insemination programmes were used, compared with artificial insemination after detected oestrus (Jordan, 2003), as was confirmed in this study. The negative effects of heat stress on cow reproductive performance were observed previously (Jordan, 2003). Contrary to the observations of this study, there was a widely observed reduction in the fertility of postpartum dairy cows inseminated in the summer compared with cows inseminated in winter, but the precise mechanism of 
this effect has not been conclusively identified (De Rensis \& Scaramuzzi, 2003). Heat stress has been reported to reduce the duration and intensity of oestrus in dairy cows leading to a reduction in the number of mounts in hot weather, compared with cold weather; hence poor detection of oestrus (Pennington et al., 1985). The interactions between season and year did not reach significant levels in either breed on most traits. However, there was an interaction between calving year and calving season on CFS for both Jersey and $\mathrm{F} \times \mathrm{J}$ cows. Therefore, $\mathrm{CFS}$ in a particular season was not consistent over the years.

\section{Conclusions}

A comparison of breed groups was conducted for reproductive performance of Jersey and $\mathrm{F} \times \mathrm{J}$ cows and heifers raised and kept under a production system generally used by dairy farmers. Crossbred cows had shorter calving to first service intervals compared with purebreds, with a larger percentage of crossbreds having their reproductive systems recovering earlier than the purebreds. Thus, a higher percentage of crossbred cows were confirmed pregnant compared with purebreds. There were no breed group differences on all the reproductive performance traits that were measured on heifers, suggesting that heifers from both breed groups have the same reproductive performance potential at young age. Although there were no differences in heifer reproductive performance between breeds, the lifetime reproductive performance of the dairy herd could be improved by practising crossbreeding.

\section{Acknowledgements}

The Eastern Cape Department of Rural Development and Agrarian Reform is acknowledged for funding this study and Elsenburg Research Institute for kind permission to use their data.

\section{References}

Anderson, T., Shaver, R., Bosma, P. \& De Boer, V., 2007. Case study: Performance of lactating Jersey and Jersey-Holstein crossbred versus Holstein cows in a Wisconsin confinement dairy herd. Prof. Anim. Sci. 23, 541-545.

Auldist, M.J., Pyman, M.F.S., Grainger, C. \& Macmillan, K.L., 2007. Comparative reproductive performance and early lactation productivity of Jersey $\times$ Holstein cows in predominantly Holstein herds in a pasturebased dairy system. J. Dairy Sci. 90, 4856-4862.

Broom, D.M., Galindo, F.A. \& Murgueitio, E., 2013. Sustainable, efficient livestock production with high biodiversity and good welfare for animals. Proc. R. Soc. B. 280, 2013-2025.

Caraviello, D.Z., 2004. Crossbreeding dairy cattle: Dairy Updates. Reprod. Genet. No 610. pp. 1-6.

Dechow, C.D., Rogers, G.W., Cooper, J.B., Phelps, M.I. \& Mosholder, A.L., 2007. Milk, fat, protein, somatic cell score, and days open among Holstein, Brown Swiss and their crosses. J. Dairy Sci. 90, 3542-3549.

De Rensis, F. \& Scaramuzzi, R.J., 2003. Heat stress and seasonal effects on reproduction in the dairy cow a review. Theriogenology 60, 1139-1151.

Dillon, P., Berry, D.P., Evans, R.D., Buckley, F. \& Horan, B., 2006. Consequences of genetic selection for increased milk production in European seasonal pasture based systems of milk production. Livest. Sci. 99, 141-158.

Du Toit, J., Van Wyk, J.B. \& Maiwashe, A., 2012. Assessment of inbreeding depression for functional herd life in the South African Jersey breed based on level and rate of inbreeding. S. Afr. J. Anim. Sci. 42, 55-62.

Fuerst-Waltl, B. \& Feurst, C., 2010. Mortality in Austrian dual purpose Fleckvieh calves and heifers. Livest. Sci. $132,80-86$.

Goddard, M., 2009. Fitness traits in animal breeding programmes. In: Adaptation and Fitness in Animal populations. Eds: Van der Werf, J., Graser, H.U., Frankham, R. \& Gondro, C., Springer, Netherlands.

Heins, B.J., Hansen, L.B. \& Seykora, A.J., 2006. Fertility and survival of pure Holsteins versus crossbreds of Holsteins with Normande, Montbéliarde, and Scandinavian Red. J. Dairy Sci. 89, 4944-4951.

Heins, B.J., Hansen, L.B., Seykora, A.J., Johnson, D.G., Linn, J.G., Romano, J.E. \& Hazel, A.R., 2008. Crossbreds of Jersey $\times$ Holstein compared with pure Holsteins for production, fertility, and body and udder measurements during first lactation. J. Dairy Sci. 91, 1270-1278.

Jordan, E.R., 2003. Effects of heat stress on reproduction. J. Dairy. Sci. 86, E104-E11.

Maiwashe, A., Nephawe, K.A., Van der Westhuizen, R.R., Mostert, B.E. \& Theron, H.E., 2006. Rate of inbreeding and effective population size in four major South African dairy cattle breeds. S. Afr. J. Anim. Sci. 36, 50-57.

Makgahlela, M.L., Banga, C.B., Norris, D., Dzama, K. \& Ng'ambi. J.W., 2008. Genetic analysis of age at first calving and calving interval in South African Holstein cattle. Asian J. Anim. Vet. Adv. 3, 197-205. 
McAllister, A.J., 2002. Is crossbreeding the answer to questions of dairy breed utilization? J. Dairy Sci. 85, 2352-2357.

Mostert, B.E., Van der Westhuizen, R.R. \& Theron, H.E., 2010. Calving interval genetic parameters and trends for dairy breeds in South Africa. S. Afr. J. Anim. Sci. 40, 156-162.

Muller, C.J.C., 2011. Can Fleckvieh genes improve performance in a dairy herd? Farmer's Weekly. pp. 100-101.

Oltenacu, P.A. \& Broom, D.M., 2010. The impact of genetic selection for increased milk yield on the welfare of dairy cows. Animal Welfare 19, 39-49.

Pennington, J.A., Albright, J.L., Diekman, M.A. \& Callahan, C.J., 1985. Sexual activity of Holstein cows: seasonal effects. J. Dairy Sci. 68, 3023-3027.

Piccand, V., Cutullic, E., Meier, S., Schori, F., Kunz, P.L., Roche, J.R. \& Thomet, P., 2013. Production and reproduction of Fleckvieh, Brown Swiss, and 2 strains of Holstein-Friesian cows in a pasture-based, seasonal-calving dairy system. J. Dairy Sci. 96, 5352-5363.

Prendiville, R., Shalloo, L., Pierce, K.M. \& Buckley, F., 2011. Comparative performance and economic appraisal of Holstein-Friesian, Jersey and Jersey $x$ Holstein-Friesian cows under seasonal pasturebased management. Irish J. Agr. Food. Res. 50, 123-140.

Pryce, J.E., Royal, M.D., Garnsworthy, P.C. \& Mao, I.L., 2004. Fertility in the high-producing dairy cow. Livest. Prod. Sci. 86, 125-135.

SAS, 2009. Statistical Analysis Systems User's Guide. SAS Institute Inc., Cary, N.C., USA.

Schaeffer, L.R., Burnside, E.B., Glover, P. \& Fatehi, J., 2011. Crossbreeding results in Canadian dairy cattle for production, reproduction and conformation. Open. Agri. J. 5, 63-72.

Smith, L.A., Cassell, B.G. \& Pearson, R.E., 1998. The effects of inbreeding on the lifetime performance of dairy cattle. J. Dairy Sci. 80, 2729-2737.

Thompson, J.R., Everett, R.W. \& Wolfe, C.W., 2000. Effects of inbreeding on production and survival in Jerseys. J. Dairy Sci. 83, 2131-2138. 